\title{
Journal of Bacteriology and

\section{Antibacterial and Wound Healing Properties of Terminalia superba Engl. and Diels (Combretaceae) in Albino Wistar Rats}

\section{Dougnon TV*, Klotoe JR, Anago Eugénie, Yaya Nadjo S, Fanou B, Loko F}

Laboratory of Research in Applied Biology, Polytechnic School of Abomey-Calavi, University of Abomey-Calavi, Cotonou, Benin

*Corresponding Author: Dougnon TV, Laboratory of Research in Applied Biology, Polytechnic School of Abomey-Calavi, University of Abomey-Calavi, 01 PO Box 2009 Cotonou, Benin, Tel: 00229977364 46; E-mail: victorien88@hotmail.com, dougnonv@yahoo.fr

Rec date: June 04, 2014; Acc date: October 16, 2014; Pub date: October 20, 2014

Copyright: (c) 2014 Dougnon TV, etal. This is an open-access article distributed under the terms of the Creative Commons Attribution License, which permits unrestricted use, distribution, and reproduction in any medium, provided the original author and source are credited.

\begin{abstract}
The objective of this study was to evaluate the antibacterial and wound healing properties of the ethanol extract of Terminalia superba's bark. In vitro tests were realized on it. Antibacterial activity and in vivo wound healing properties of the ethanol extract on infected lesions by reference strains of Escherichia coli ATCC 25922 and Staphylococcus aureus ATCC 25923 in Wistar rats were also evaluated. Thirty-two rats were divided into eight lots of four rats each. Two lots infected and treated with gentamicin, two control groups infected but untreated and a negative control group nor uninfected nor untreated were used. The last three lots were treated with the ethanol extract.

Bacteriological tests on the reference strain of S. aureus ATCC 25923 and E. coli ATCC 25922 respectively showed a Minimum Inhibitive Concentration of $0.078 \mathrm{mg} / \mathrm{ml}$ and $10 \mathrm{mg} / \mathrm{ml}$. The ethanol extract has a real healing potential and antibacterial activity against reference strains used. These antibacterial properties engage $T$. superba in the process of developing an improved traditional medicine.
\end{abstract}

Keywords: Terminalia superba; Antibacterial properties

\section{Introduction}

Since the insertion of antibiotics in human and veterinary medicine, antibiotic resistance problems in bacteria started increasing consistently [1,2]. This expansion of multi-resistant germs is due to the self-medications and the misuse of medicines. The raising of therapeutic failures due to the emergence of antibiotics multi-resistant germs requires the use of new and effective sources that are cheap and more accessible for our populations. These requirements could therefore be met by pharmacopoeia plants. Thus, Africa's biodiversity represent an important asset in searching new therapeutic approaches against infections caused by multi-resistant bacteria. Many species of plants with therapeutic properties were recorded with pharmacognosia research [3-5].

Therefore several species of plants with antibacterial potential were recorded in the literature. Out of these plants, Terminalia superba turned out to be effective with its inhibitive properties against the growth of betalactamin multi-resistant bacteria. These properties has been explained by production of broad-spectrum betalactamase [6]. $T$. superba is widespread in West and Central Africa. It is known for its multiple qualities such as antifungal [7] and hypoglycemic ones [8]. According to the literature, T. superba is useful to treat infectious and parasitic diseases. Usually, the bark of the plant is the most used. Alone or in combination, it serves to treat some broncho-pulmorary ailments [5], diarrhea and gonorrhea [4]. The confirmation of the antibacterial properties of T. superba needs the demonstration of its therapeutic effectiveness. It is then important to identify the best introduction way according to the degree of purity of the extract used. Moreover it seemed unachievable for our research team to apply the plant as ethanol extract by oral route. Hence the cutaneous application has been imposed for this study. Furthermore, in developing countries, cutaneous infected wounds are very common because of the poor hygienically conditions [9].

This information reinforces the choice about the search for the antibacterial effects of T. superba on cutaneous infections. Wound healing involves many mechanisms. These mechanisms were ascribed to some chemical lineages extracted from plants.

\section{Material}

T. superba was the vegetable material. Animal material was about both sexes of albino Wistar rats with a body weight ranging from 200 to 300 grams. These rats were bred in the animal house of the Research Laboratory of Applied Biology.

\section{Methods}

It was an experimental study with two steps. First of all, in vitro step was carried out on the reference strains of $S$. aureus ATCC 25923 and E. coli ATCC 25922. Then in vivo step was done on the Wistar rats.

\section{Preparation of the ethanol extract}

The barks of $T$. superba were dried under an ambient temperature of $25^{\circ} \mathrm{C}$ and then powdered. $1500 \mathrm{ml}$ of ethanol at $96 \%$ was added to $150 \mathrm{~g}$ of powder. The mixture was subjected to a continuous agitation for 72 hours and then filtered. The filtrate was evaporated using a BUCHI ROTAVAPOR RE 300. The obtained ethanol extract has then been used for the tests on the rats. In order to determine the needed amount of extract of the study, this test was repeated as several times as possible. Finally, the yield was computed in accordance with the formula used by et al. [10]. 


\section{In vitro assessment of the antibacterial properties of the ethanol extract}

The antibacterial properties of $T$. superba were assessed to determine the minimal inhibitive concentration of the extract towards the reference strains of $S$. aureus ATCC 25923 and E. coli ATCC 25922. The reference strains were collected from the National Laboratory of Public Health of Benin and subcultured on Eosine Methylen Blue and Chapman respectively for E. coli and S. aureus.

\section{Determination of the minimal inhibitive concentration (MIC)}

The plant extract was dissolved in DMSO at $10 \%$ for a concentration of $100 \mathrm{mg} / \mathrm{ml}$. The extract's sterility was verified by sowing on Mueller Hinton (MH) and Tryptocase soja agar. Dilutions of $50 \mathrm{mg} / \mathrm{ml}$ at $3.10-3$ were made in sterile distilled water. The original concentration of $100 \mathrm{mg} / \mathrm{ml}$ has also been tested. For the test's validation, some controls were performed by sowing the distilled water and the DMSO on MH in order to verify their sterility. Likewise, a bacterial suspension at 3.105 germs per $\mathrm{ml}$ was sowed on $\mathrm{MH}$ media and also on MH+DMSO media to check for the effect of DMSO on the bacterial growth. An enough colony of each strain was sowed in $5 \mathrm{ml}$ of Trytocase Soja broth. This suspension was incubated at $37^{\circ} \mathrm{C}$ for 18 to 24 hours. At the second day, the bacterial suspension was diluted at $1 / 100$. The concentration of that dilution was around 106 bacteria per $\mathrm{ml}$. In some Petri dishes, $2 \mathrm{ml}$ of each extract dilutions was mixed with $18 \mathrm{ml}$ of melted $\mathrm{MH}$ agar. The final concentrations of the extract in the Petri dishes overlapped from $10 \mathrm{mg} / \mathrm{ml}$ to $3.10-4 \mathrm{mg} / \mathrm{ml}$. After homogenization and solidification, the Petri dishes were dried for 30 minutes at $37^{\circ} \mathrm{C} .50 \mu \mathrm{l}$ of the bacterial suspension's dilution was laid out on the Petri dishes and these are then incubated at $37^{\circ} \mathrm{C}$ for 18 to 24 hours. The Petri dishes were read after incubation and the MIC was determined.

\section{In vivo evaluation of the antibacterial effect and wound healing potential of $T$. superba}

The Wistar rats were divided into eight lots of four rats each. All rats of the same lots were treated in identical conditions. The antibacterial effect and the wound healing potential of the ethanol extract of $T$. superba's bark were evaluated after induction of lesions that are later infected by $E$. coli and $S$. aureus.

\section{Induction of lesions}

After measuring their weight, the rats were anaesthetized by intraperitoneal injection of thiopental at $60 \mathrm{mg} / \mathrm{kg}$ body weight. After shaving the back of the rats, an aseptic surgery was applied at that area. By excision, $2.25 \mathrm{~cm}^{2}$ of wound was created using a sterile blade from the shaved area up to the under cutaneous tissue by taking care for the dermis [11].

\section{Infection of the lesions}

After the step of lesions' induction, E. coli and $S$. aureus were used to infect them. These germs have been subcultured on EMB and Chapman respectively for $E$. coli and $S$. aureus. A bacterial suspension was then prepared in Tryptocase Soja agar. This bacterial suspension was diluted in a sterile distilled water so as to obtain $10^{6}$ bacteria per $\mathrm{ml} .0 .1 \mathrm{ml}$ of that suspension was then applied on the created lesions in rats. After 24 hours, a sowing was achieved to testify the presence of bacterial infection. The procedure was modified regarding the technique used by Abo et al. [12]. The lesions were treated topically 24 hours after their infection and then once every 2 days for 21 days.

The various lots of rats used for the experimentation were distributed as follow:

Lot 1: negative control rats, lesions neither infected nor treated

Lot 2: rats with uninfected lesions but treated with the ethanol extract of T. superba's barks at $100 \mathrm{mg} / \mathrm{ml}$ of concentration

Lot 3: rats with lesions infected by $E$. coli and treated with the ethanol extract of $T$. superba's barks at $100 \mathrm{mg} / \mathrm{ml}$ of concentration

\section{Lot 4: rats with lesions infected by $E$. coli but untreated}

Lot 5: rats with lesions infected by $S$. aureus and treated with the ethanol extract of $T$. superba's barks at $10 \mathrm{mg} / \mathrm{ml}$ of concentration

Lot 6: rats with lesions infected by $S$. aureus and untreated

Lot 7: rats with lesions infected by $S$. aureus and treated with gentamicin at $40 \mathrm{mg} / \mathrm{ml}$ of concentration (positive control)

Lot 8: rats with lesions infected by $E$. coli and treated with gentamicin at $40 \mathrm{mg} / \mathrm{ml}$ concentration (positive control)

\section{Parameters assessment}

The presence of the bacteria was noticed after the sowing every 02 days following the infections of the lesions and their treatment with the ethanol extract of T. superba's barks in rats. For E. coli, the culture was done in EMB to assess the inhibitive activity of T. superba on the bacteria. It was the same procedure for $S$. aureus where the sowing was done in Chapman. The identification and the resistance profile of each reference strains were made at the beginning and the end of the protocol.

After taking the picture of each wound, the gradual changes in the lesions' evolution were recorded by drawing their edge on a clean and transparent paper every 04 days after the infection and treatment with the ethanol extract. The whole process lasted 21 days [12].

\section{Statistical Analysis}

Data were analyzed using analysis of variance (ANOVA) with repeated measures, the simple variance test, and Waller Duncan multiple comparison test. The figures were drawn with GraphPad Prism software. The statistical analyses were done with the software $\mathrm{R}$ version 3.0.2. The significant level used was $5 \%$.

\section{Results}

\section{Antibacterial properties of the ethanol extract}

This study allowed determining the minimal inhibitive concentration of the ethanol extract on the reference strains of E. coli ATCC 25922 and $S$. aureus ATCC 25923. $10 \mathrm{mg} / \mathrm{ml}$ is the concentration that inhibited the growth of E. coli ATCC 25922. The MIC obtained for the reference strain $S$. aureus ATCC 25923 is 0,078 $\mathrm{mg} / \mathrm{ml}$. The culture of $S$. aureus and $E$. coli on $\mathrm{MH}$ (30 colonies) and on $\mathrm{MH}$ added with DMSO (30 colonies) revealed that DMSO have no inhibitive action on these strains. The various concentrations tested and the MIC determined is displayed in the Table 1. 
Citation: Dougnon TV, Klotoe JR, Eugénie A, Nadjo YS, Fanou B, et al. (2014) Antibacterial and Wound Healing Properties of Terminalia superba Engl. and Diels (Combretaceae) in Albino Wistar Rats. J Bacteriol Parasitol 5: 206. doi:10.4172/2155-9597.1000206

Page 3 of 6

\begin{tabular}{|c|c|c|c|}
\hline & Presence or absence of colony & & \\
\hline & Concentrations tested $(\mathrm{mg} / \mathrm{ml})$ & S. aureus & E.coli \\
\hline 10 & & - & - \\
\hline 5 & & - & + \\
\hline 2.5 & & - & + \\
\hline 1.25 & & - & + \\
\hline 0.625 & & - & + \\
\hline 0.312 & & - & + \\
\hline 0.156 & & - & + \\
\hline 0.078 & & - & \\
\hline 0.039 & & + & \\
\hline 0.019 & & + & \\
\hline 0.009 & & + & \\
\hline 0.004 & & + & \\
\hline 0.002 & & + & \\
\hline 0.001 & & + & \\
\hline
\end{tabular}

Table 1: Minimal inhibitive concentration of the strains . - : Absence of Colony ; +: Presence of Colony

In vivo assessment of the antibacterial properties and the wound healing potential of the ethanol extract

Antibacterial and wound healing properties of the ethanol extract on the lot of rats whose lesions were infected by E. coli: The bactericidal effect of the ethanol extract at $100 \mathrm{mg} / \mathrm{ml}$ on the reference strain of E. coli ATCC 25922 was noticed after 05 days. The same outcome was obtained after 15 days with the positive control and after 03 days in the lots treated with gentamicin at $40 \mathrm{mg} / \mathrm{ml}$ (Table 2).

\begin{tabular}{|l|l|l|l|l|l|l|l|l|l|l|}
\hline $\begin{array}{l}\text { Days } \\
\text { Treatments }\end{array}$ & D3 & D5 & D7 & D9 & D11 & D13 & D15 & D17 & D19 & D21 \\
\hline Positive control & + & + & + & + & + & + & - & - & - & - \\
\hline Reference & - & - & - & - & - & - & - & - & - & - \\
\hline Treated & + & - & - & - & - & - & - & - & - & - \\
\hline
\end{tabular}

Table 2: Bactericidal effect of the ethanol extract. +: Presence of Colonies - : Absence of Colonies D: Day

At the end of the treatment, a significant decreasing of the mean of the lesions' diameters was recorded in the rats treated with the ethanol extract at $100 \mathrm{mg} / \mathrm{ml}$ compared to the control. Likewise, a significant reduction of the mean of the lesions' diameters was recorded among the rats treated with gentamicin and the control rats. The difference between the control group and the one treated with the extract was noticed from D7 to D17. Although, that difference was recorded from D3 to D19 between the control lot and the reference lot. In fact, the lot treated with the ethanol extract at $100 \mathrm{mg} / \mathrm{ml}$ healed completely after 17 days, the reference lot after 21 days and the control lot healed beyond 21 days (Figure 1).

\section{Antibacterial and wound healing properties of the ethanol extract on the lot of rats whose lesions were infected by $S$. aureus}

The Table 2 show the bactericidal effect of the ethanol extract on the reference strain of $S$. aureus ATCC 25923. The bactericidal effect of the ethanol extract on the reference strain of $S$. aureus ATCC 25923 was recorded after 15 days. In fact, no bacterial growth was observed after the sowing of a sample realized from the infection site on Chapman (Table 2). That result was obtained after 9 days in the positive control group and 03 days with the lot treated with gentamicin at $40 \mathrm{mg} / \mathrm{ml}$ (Figure 2). A significant reduction of the mean of the lesions' diameters was recorded in the rats treated with the ethanol extract at $10 \mathrm{mg} / \mathrm{ml}$ compared to the positive control group. 
Citation: Dougnon TV, Klotoe JR, Eugénie A, Nadjo YS, Fanou B, et al. (2014) Antibacterial and Wound Healing Properties of Terminalia superba Engl. and Diels (Combretaceae) in Albino Wistar Rats. J Bacteriol Parasitol 5: 206. doi:10.4172/2155-9597.1000206

Page 4 of 6

Likewise, a significant reduction of the mean of the lesions' diameters was recorded among the reference lots and the control rats.

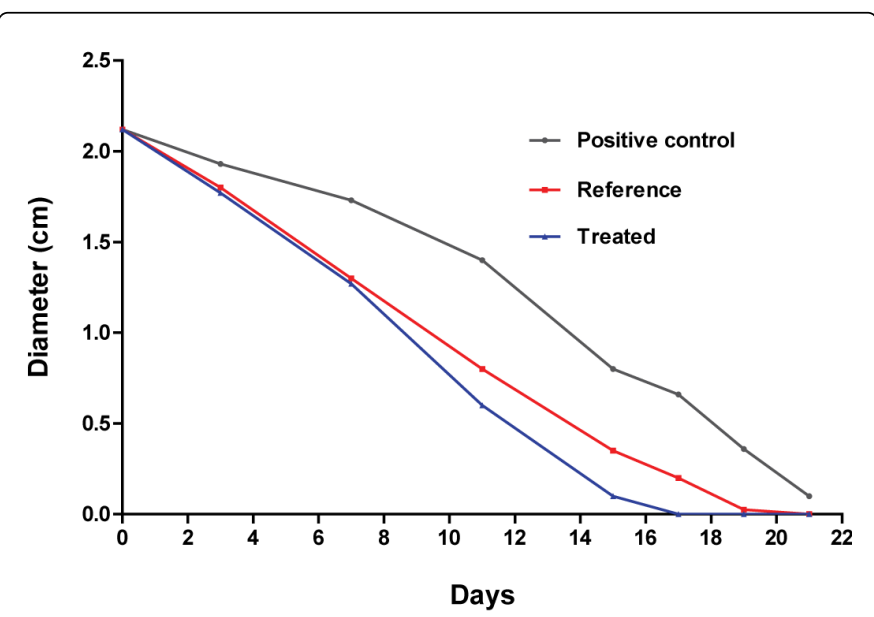

Figure 1: Curve relating the retraction of the infected lesions by $E$. coli made in the lots of rats.

That decreasing was noticed between the control group and the one treated with the extract at $10 \mathrm{mg} / \mathrm{ml}$ from D0 to D11 and D19, but at D7 for the control lot and the reference lot. These findings translate a complete healing of the lesions of the lots treated with the ethanol extract after 19 days whereas the reference lot treated with gentamicin healed completely after 21 days and the positive control group healed beyond 21 days (Figure 2).

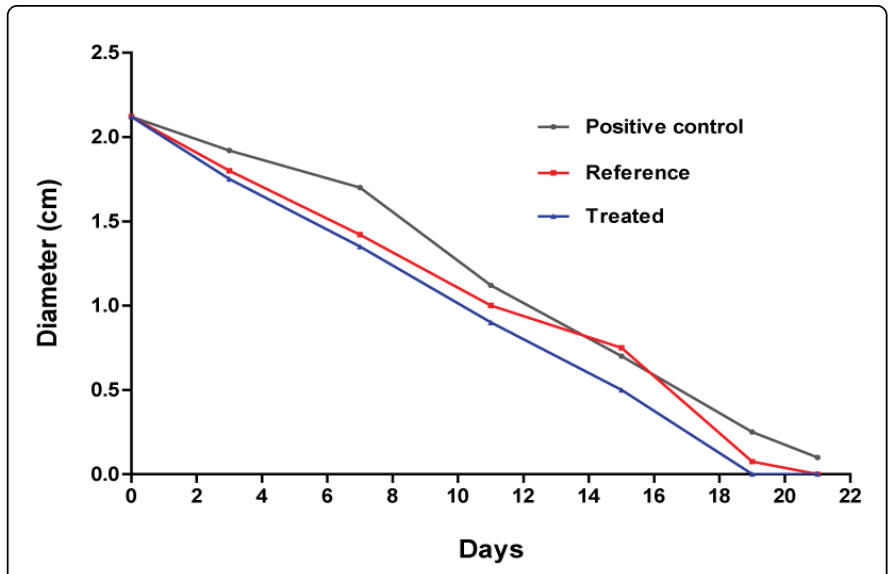

Figure 2: Curve relating the retraction of the infected lesions by $S$. aureus made in the lots of rats.

\section{Identification of the resistance profile of the strains}

The Table 3 displays the resistance of the strains at the beginning and the end of the protocol. The strains of $S$. aureus are coagulase + and Dnase + . From the results of the antibiogram, we can deduce that the resistance profiles are identical and it is really matter of reference strains of E. coli and $S$. aureus at the beginning and the end of the protocol.

\begin{tabular}{|c|c|c|c|c|}
\hline $\begin{array}{l}\text { Type of strains } \\
\text { Antibiotics }\end{array}$ & $\begin{array}{l}\text { Extracted strain } \\
\text { (S. aureus) }\end{array}$ & $\begin{array}{l}\text { Reference strain } \\
\text { (S. aureus) }\end{array}$ & $\begin{array}{l}\text { Reference strain } \\
\text { (E. coli) }\end{array}$ & $\begin{array}{l}\text { Extracted strain } \\
\text { (E. coli) }\end{array}$ \\
\hline Gentamicin & $\mathrm{s}$ & $\mathrm{s}$ & $\mathrm{s}$ & $\mathrm{s}$ \\
\hline Ofloxacin & $\mathrm{s}$ & $\mathrm{s}$ & $S$ & $S$ \\
\hline Amoxicillin & $\mathrm{s}$ & $\mathrm{s}$ & $\mathrm{s}$ & $\mathrm{s}$ \\
\hline Amoxicillin+clavulanic acid & $\mathrm{s}$ & $\mathrm{s}$ & $\mathrm{s}$ & $\mathrm{s}$ \\
\hline Ceftriaxone & $\mathrm{s}$ & $\mathrm{s}$ & $\mathrm{s}$ & $\mathrm{s}$ \\
\hline Ciprofloxacin & $S$ & $S$ & S & S \\
\hline Nitrofurantoïne & $\mathrm{s}$ & $\mathrm{s}$ & $\mathrm{s}$ & $\mathrm{s}$ \\
\hline Oxacillin & $\mathrm{s}$ & $\mathrm{s}$ & $\mathrm{s}$ & $\mathrm{s}$ \\
\hline Chloramphenicol & S & s & S & S \\
\hline Tetracycline & $\mathrm{s}$ & $\mathrm{s}$ & $\mathrm{s}$ & $\mathrm{s}$ \\
\hline Erythromycin & $S$ & $S$ & $S$ & S \\
\hline Pristinamycin & $S$ & $\mathrm{~s}$ & $\mathrm{~s}$ & $\mathrm{~s}$ \\
\hline Sulfamethoxazole+trimethoprim & $\mathrm{s}$ & $\mathrm{s}$ & $\mathrm{s}$ & $\mathrm{s}$ \\
\hline
\end{tabular}

Table 3: Resistance Profile of the strains. S: Sensible 


\section{Wound healing potential of the ethanol extract on the non- infected lesions done in rats}

A significant reduction of the mean of the lesions' diameters was recorded $(\mathrm{p}<0.01)$ in the treated lot compare to the control. This statistical difference was registered from D7 and D19 (Figure 3).

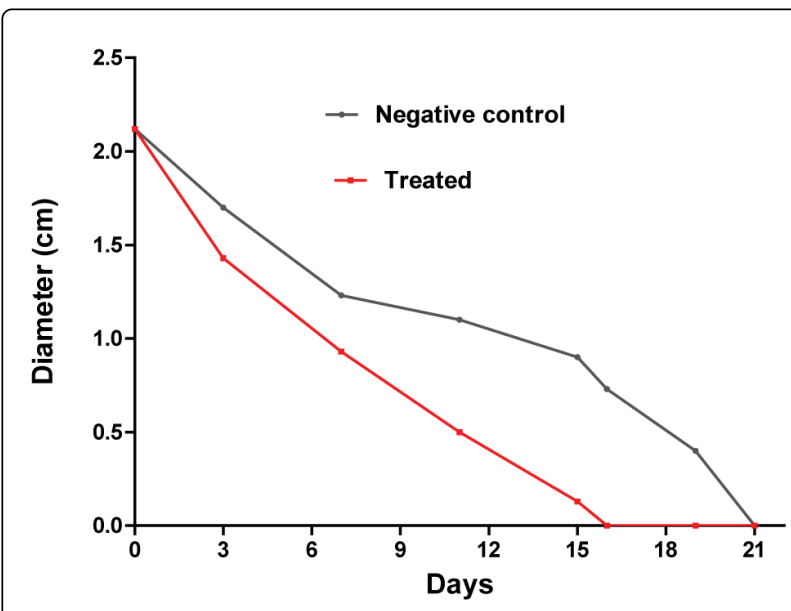

Figure 3: Differences between negative and treated lots.

\section{Discussion}

The various concentrations tested for the $S$. aureus strain allowed to determine a MIC of $0.078 \mathrm{mg} / \mathrm{ml}$. The research works on the barks of Terminalia superba concern its anti-parasitic properties on trypanosome, its vasodilator effect, its anti-diabetic properties and its inhibitive action on alpha-glycosidase [8,13-15]. According to our knowledge, no study achieved on the ethanol extract of Terminalia superba's barks about the strain $S$. aureus ATCC 25923 was underlined in the literature. Moreover, some studies demonstrated the antibacterial activity of several else species from Terminalia genus (Combretaceae) on various microorganism such as $S$. aureus [16]. Thangavelu et al., [10] have proved that ethanol extracts of Terminalia chebula and Terminalia bellerica possess an antibacterial activity on $S$. aureus at MIC of $1.562 \mathrm{mg} / \mathrm{ml}$.

The lowest MIC obtained in this study could be due to the main feature of the reference strain that is to develop few resistance mechanisms against antibiotics. Furthermore, the $\mathrm{MH}$ media classically used to determine the MIC of the non-selective germs is less favorable for a fast growth of $S$. aureus than the $\mathrm{MH}$ media with $5 \%$ of $\mathrm{NaCl}$ required in the current practice in laboratory for revealing heterogenic populations of $S$. aureus [17]. Thangavelu et al. [10] do not have accurate data for this issue about the strain of $S$. aureus used. Others research works demonstrated that tannins possess an antimicrobial activity [18]. This could justify the antibacterial activity of our extract that contains a lot amount of tannins. The inhibition of the $E$ coli strain was recorded at $10 \mathrm{mg} / \mathrm{ml}$ of concentration of the ethanol extract in $\mathrm{MH}$ media. It corresponds to the concentration of inhibition at $100 \%$ of $E$. coli [6]. This plant seems to conceal some active substances that inhibit the metabolic process involves in the growth of these bacteria.

The results of this study show a wound healing potential of the ethanol extract of Terminalia superba's bark. A significant difference was observed from D7 to D19 in the lot of the rats whose lesions were not infected but treated with the ethanol extract of Terminalia superba's bark compared to the rats of the negative control group. This could originate from the presence in that plant of some tannins that have astringents properties [18]. Multiple phytochemical compounds like alkaloids are known for favoring the curative process of the wound due to their antioxidant and antimicrobial activities [18]. The main active agent of the ethanol extract responsible of the lesions' retraction and its mechanism is not elucidated. However, the phytochemical screening indicated the presence of flavonoids. These compounds are known to have a curative effect on wounds [19].

Others studies achieved on others species of Terminalia genus. Terminalia arjuna and Terminalia bellerica (Combretaceae) showed that the organs of these plants (respectively the stem and the fruit) are used to heal wounds or cuts [20]. Tannins and flavonoids are present in both plants. That can explain the wound healing potential of our plant because of the similarity of the phytochemical compounds. It also comes out of this study that the ethanol extract has an in vivo antibacterial effect on E. coli. Gentamicin was used as a reference drug. Amino glycosides act on the ribosome by interfering on the link with the aminoacyl-RNAt and thus stop the protein synthesis [21].

Therefore, the ethanol extract of Terminalia superba's bark could contain some amino and glycosides compounds responsible of its antibacterial activity on infected wounds [12]. Any in vivo research about the antibacterial effect of the ethanol extract of Terminalia superba's bark was not achieved on that bacterium. However the in vitro and in vivo results demonstrate that that plant has a real antibacterial effect on E. coli. The literature reports also these antimicrobial effects. According to Anago [6], T. superba is in vitro active on E. coli. Moreover the results obtain with $S$. aureus proved the in vitro antibacterial effect with a MIC of $0.078 \mathrm{mg} / \mathrm{ml}$, but in vivo, the disappearance of the germs was observed after 15 days under treatment with the ethanol extract. The lateness to healing and elimination of $S$. aureus on the infected lesions is paradoxical regarding the very low MIC obtained at the in vitro bacteriological tests. It could be evoked a faster speed of colonization of the infection site by $S$. aureus compare to E. coli.

\section{Conclusion}

The results of this study showed that the ethanol extract of Terminalia superba's bark is effective against the reference E. coli ATCC 25922 strain and possess a wound healing potential. That extract is also very active in vitro against the reference strain of $S$. aureus ATCC 25923 and its antibacterial effect was noticed in vivo after 15 days of treatment. It will be interesting to test greater concentrations of that extract on infected lesions or to create a formulation from the powder of the bark of Terminalia superba having a thick consistency in order to prolong the action duration of the formulation in contact with the lesions.

\section{References}

1. Brisson-Noel A, Trieu-Cuot P, Sougakoff W, Courvalin P (1989) Current aspects of bacterial resistance to antibiotics. Ann Biol Clin 47: 98-101.

2. Oteo J, Lázaro E, de Abajo FJ, Baquero F, Campos J; Spanish members of EARSS (2005) Antimicrobial-resistant invasive Escherichia coli, Spain. Emerg Infect Dis 11: 546-553.

3. Adjanohoun EJ, Adjakidje V, Ake-Assi MRA, Akouegninou L, Zohoun Th, et al. (1989) Médecine traditionnelle et pharmacopée : contribution 
Citation: Dougnon TV, Klotoe JR, Eugénie A, Nadjo YS, Fanou B, et al. (2014) Antibacterial and Wound Healing Properties of Terminalia superba Engl. and Diels (Combretaceae) in Albino Wistar Rats. J Bacteriol Parasitol 5: 206. doi:10.4172/2155-9597.1000206

Page 6 of 6

aux études ethnobotaniques et floristiques en République populaire du Bénin. Paris.

4. Neuwinger HD (2000) African Traditional Medicine: A Dictionary of Plant Use and Applications. Stuttgart: Editions Medpharm Scientific Publishers.

5. Akoegninou A, Van der Burg WJ, Van der Maesen LJG (2006) Flore analytique du Bénin. Edition Wageningen University papers 1: 624-631.

6. Anago EAA (2009) Activités antibactériennes de quelques plantes de la pharmacopée Africaine sur des souches de E. coli productrices de bêtalactamases. Thèse de Doctorat en Biochimie à l'Université d'Abomey-calavi 91-103

7. Ahon MG, Akapo-Akue JM, Kra MA, Ackah JB, Zirihi NG, et al. (2011) Antifungal activity of the aqueous and hydro-alcoholic extracts of $\mathrm{T}$. superba Engl \& Diels on the in vitro growth of clinical isolates of pathogenic fungi. Agric. Biol JN Am 2:250-257.

8. Wansi JD, Lalemand MC, Chiozem DD, Toze FAA, Mbaze LM, et al. ( 2007) alpha- glucosidase inhibitory constituents from stem bark of Terminalia superba (Combretaceae). Phytochemistry Elsevier; 68:2096-100.

9. Senthil Kumar M, Sripriya R, Vijaya Raghavan H, Sehgal PK (2006) Wound healing potential of Cassia fistula on infected albino rat model. J Surg Res 131: 283-289.

10. Thangavelu RN, Jesuthankaraj GN, Arunagiri C, Suneera L, Melda D (2012) Evaluation of antibacterial, antioxidant and wound healing properties of seven traditional medicinal plants from India in experimental animals. Asian pacific Journal of Tropical Biomedicine 1245-1253.

11. Conserva ML, Bastos MAL, Houly RLS, Andrade VS, Rocha EMM, et al (2011) Antimicrobial and wound healing activities of Piper hayneanum. J Chem Pharm Res 3:213-222.
12. Abo A, Olugbuyiro JAO, Famakinde SA (2004) Anti-infective and wound healing properties of Flabellaria paniculata. African Journal of Biomedical Research 7: 85-87.

13. Adewunmi CO, Agbedahunsi JM, Adebajo AC, Aladesanmi AJ, Murphy $\mathrm{N}$, et al. (2001) Ethno-veterinary medicine: screening of Nigerian medicinal plants for trypanocidal properties. J Ethnopharmacol 77: 19-24.

14. Dimo T, Laurent F, Rakotonirina SV, Tan PV, Kamtchouing P, et al. (2006) Methanol extract of Terminalia superba induces endotheliumindependent relaxation of rat thoracic aorta. Pharmazie 61: 470-473.

15. Kamtchouing P, Kahpui SM, Dzeufiet PD, Tédong L, Asongalem EA, et al. (2006) Anti-diabetic activity of methanol/methylene chloride stem bark extracts of Terminalia superba and Canarium schweinfurthii on streptozotocin-induced diabetic rats. J Ethnopharmacol 104: 306-309.

16. Chandrabhan S, Sachin K, Choudhary HS (2011) In vitro antimicrobial study of the aqueous and methanolic extracts of certain selected medicinal plants. J Chem Pharm Res 3:854-860.

17. Carbonnelle B, Denis F, Marmonier A, Pinon G, Vargues R (1987) Bactériologie Medicale :Techniques Usuelles. Paris.

18. Bruneton J (1989) Pharmacognosie, phytochimie-plantes médicinales. Paris.

19. Shafaghat A, Salimi F, Aslaniyan N, Shoaei Z (2010) Flavonoids and an ester derivative isolated from Galium verum L. World Appl Sci J 11:473-477.

20. Subramanian R, Krishnasamy G, Devaraj A, Sethuraman P, Jayakumaraj R (2011) Wound healing ethnopharmacological potentials of selected medicinal plants used by Malayi tribes. Int Res J Pharma 2: 132-137.

21. Van Bambeke F, Tulkens P (2007) Syllabus national belge de Pharmacologie - Pharmacologie et Pharmacothérapie anti-infectieuse. 